\title{
Use of cryogenic components of propellants for liquid-propellant rocket engines and in life support systems of manned space vehicles \\ Sergei $A$. Orlin ${ }^{(\text {a) }}$ \\ (a) Bauman Moscow State Technical University Moscow, 105005, Russia
}

\begin{abstract}
The cited materials show the use of oxygen, hydrogen, liquefied natural gases (methane) and fluorine as components of the fuel for liquid-propellant rocket engines (LRE). The reasons for the need to use oxygen as an oxidizing agent are indicated. The advantages and disadvantages are disclosed from the point of view of using the listed components as fuel elements for liquid-propellant rocket engines. The issues of ecology when using the considered fuels are reviewed. Shown not only the use of cryogenic components as fuel for LRE, but also in life support systems in manned spacecraft in space research.
\end{abstract}

Keywords: oxygen, hydrogen, fluorine, liquid propellant rocket engines, life support systems, ecology.

\section{INTRODUCTION}

Space exploration in the 20-th century has become widely known in the world thanks to three events: the launch of the first artificial Earth satellite in the USSR on October 4, 1957, the orbital flight of the first «manned astronautics» apparatus «Vostok» with the first Earth cosmonaut, a citizen of the USSR Yuri Gagarin on April 12, 1961 and an expedition to visit the lunar surface as a result of the «Apollo» expedition organized by the USA. On November 21, 1969, a man of planet Earth, US citizen Neil Armstrong, stepped onto the surface of the moon: «That's one small step for man - a giant leap for mankind». In total, in the period from 1969 to 1972 under the «Apollo» program, six flights to the Moon were made, during which 12 cosmonauts visited the lunar surface.

All of the above became possible thanks to the work of rocketry enthusiasts in the USSR S.P. Korolev, who headed space exploration, and his collaborator M.K. Tikhomirov, who proposed the «package» scheme, which became the basis for the design of the R-7 rocket system, the creator of rocket engines V.P. Glushko and many others.

One of the main elements of any rocket system is the propulsion system (PS). The most acceptable for rockets with a high thrust (about hundreds of tons) is a propulsion system with a liquid-propellant rocket engine (LRE), first used by the American designer R. Goddard in 1929.

A LRE is an internal combustion engine, where the conversion of chemical energy released during fuel combustion in a combustion chamber (CC) into kinetic energy occurs. Thanks to this energy, the products of fuel combustion, 
which are the working fluid of the engine, accelerating in the engine nozzle and flowing out of it, form the engine thrust.

The combustion process is based on the oxidation of one of the propellant components by another; therefore, all liquid-propellant rocket engine fuels consist of an oxidizer and combustible components. In most cases, oxygen is used as an oxidizing agent in its pure form or as substances containing it. The combustible component is carbon or hydrogen compounds. Both components of the fuel are in the liquid phase.

The table contains a list of fuels currently used for LRE. The parameters of engines operating on these fuels are given, and the properties of combustion products are presented: components, their density $\rho_{\mathrm{o}}$ and $\rho_{\mathrm{c}}$, indicating the temperature of the liquid phase and specific heat of combustion Q. The types of engines, the optimal mass ratio of the components $\mathrm{k}_{\mathrm{m}}$, thrust in the void are also indicated $\mathrm{P}_{\mathrm{v}}$ and the temperature of the combustion products in the combustion chamber $T_{c c}$, the specific impulse in the void Io and the conditional value of the fuel density $\rho_{\mathrm{f}}$, which determines the mass characteristics of the rocket system.

List of rocket fuels

\begin{tabular}{|c|c|c|c|c|c|c|}
\hline \multicolumn{2}{|c|}{ Fuel } & \multirow[b]{2}{*}{ 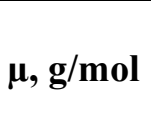 } & \multirow[b]{2}{*}{$\mathrm{Q}, \mathrm{kJ} / \mathrm{kg}$} & \multirow[b]{2}{*}{$\begin{array}{l}\text { LRE, type } \\
\text { of RE }\end{array}$} & \multirow[b]{2}{*}{$\mathbf{k}_{\mathbf{m}}$} & \multirow[b]{2}{*}{ Pv, ts } \\
\hline $\begin{array}{l}\text { Oxidizer } \rho_{o}, \\
\mathrm{~g} / \mathrm{cm}^{3}\end{array}$ & $\begin{array}{c}\text { Fuel } \rho_{\mathrm{c}} \\
\mathrm{g} / \mathrm{cm}^{3}\end{array}$ & & & & & \\
\hline $\begin{array}{c}\mathrm{N}_{2} \mathrm{O}_{4} \\
\rho_{\mathrm{o}}=1,44 \\
\mathrm{~T}_{\mathrm{cc}}=294 \mathrm{~K} \\
\left(21^{\circ} \mathrm{C}\right)\end{array}$ & $\begin{array}{c}\text { UDMH } \\
\rho_{\mathrm{c}}=0,9 \\
\mathrm{~T}_{\mathrm{cc}}=298 \mathrm{~K} \\
\left(25^{\circ} \mathrm{C}\right)\end{array}$ & 24 & 6000 & RD-257 & 2,67 & 15,7 \\
\hline $\begin{array}{c}\text { Oxygen } \\
\mathrm{O}_{2} \\
\rho_{\mathrm{o}}=1,44 \\
\mathrm{~T}_{\mathrm{cc}}=294 \mathrm{~K} \\
\left(-183^{\circ} \mathrm{C}\right)\end{array}$ & $\begin{array}{c}\text { Kerosene } \\
\mathrm{CH}_{1.96} \\
\rho_{\mathrm{c}}=0,83 \\
\mathrm{~T}_{\mathrm{cc}}=298 \mathrm{~K} \\
\left(25^{\circ} \mathrm{C}\right)\end{array}$ & 22 & 9200 & RD-170 & 2,6 & $1854=740$ \\
\hline $\begin{array}{c}\text { Oxygen } \\
\mathrm{O}_{2}\end{array}$ & $\begin{array}{c}\text { Hydrogen } \\
\mathrm{H}_{2} \\
\rho_{\mathrm{c}}=0,07 \\
\mathrm{~T}_{\mathrm{cc}}=20 \mathrm{~K} \\
\left(-253^{\circ} \mathrm{C}\right)\end{array}$ & 13,7 & 13400 & $\frac{\mathrm{RD}-57}{0120}$ & $\frac{6,2}{6}$ & $\frac{44}{204}$ \\
\hline $\begin{array}{c}\text { Fluorine } \mathrm{F}_{2} \\
\rho_{\mathrm{o}}=1,5 \\
\mathrm{~T}_{\mathrm{cc}}=85 \mathrm{~K} \\
\left(-188^{\circ} \mathrm{C}\right)\end{array}$ & $\begin{array}{c}\text { Hydrogen } \\
\mathrm{H}_{2}\end{array}$ & 16 & - & RD-350 & 16,2 & 10 \\
\hline $\begin{array}{c}\text { Oxygen } \\
\mathrm{O}_{2}\end{array}$ & $\begin{array}{c}\text { Methane } \\
\mathrm{CH}_{4} \\
\rho_{\mathrm{c}}=0,43 \\
\mathrm{~T}_{\mathrm{cc}}=110 \mathrm{~K} \\
\left(-163^{\circ} \mathrm{C}\right)\end{array}$ & 22 & - & RD-190 & 3,4 & 100 \\
\hline
\end{tabular}




\begin{tabular}{|c|c|c|c|c|c|}
\hline \multicolumn{2}{|c|}{ Fuel } & \multirow[t]{2}{*}{ pk, MPa } & \multirow[t]{2}{*}{$\mathbf{T}_{\mathrm{cc}}, \mathbf{K}$} & \multirow[t]{2}{*}{$\mathbf{I}_{\mathrm{v}}, \mathbf{s}$} & \multirow[t]{2}{*}{$\rho_{\mathrm{f}}, \mathbf{g} / \mathrm{cm}^{3}$} \\
\hline $\begin{array}{l}\text { Oxidizer } \rho_{o}, \\
\mathrm{~g} / \mathrm{cm}^{3}\end{array}$ & $\begin{array}{l}\text { Fuel } \rho_{\mathrm{c}} \\
\mathrm{g} / \mathrm{cm}^{3}\end{array}$ & & & & \\
\hline $\begin{array}{c}\mathrm{N}_{2} \mathrm{O}_{4} \\
\rho_{\mathrm{o}}=1,44 \\
\mathrm{~T}_{\mathrm{cc}}=294 \mathrm{~K} \\
\left(21^{\circ} \mathrm{C}\right)\end{array}$ & $\begin{array}{c}\text { UDMH } \\
\rho_{\mathrm{c}}=0,9 \\
\mathrm{~T}_{\mathrm{cc}}=298 \mathrm{~K} \\
\left(25^{\circ} \mathrm{C}\right)\end{array}$ & 24 & 6000 & RD-257 & 2,67 \\
\hline $\begin{array}{c}\text { Oxygen } \\
\mathrm{O}_{2} \\
\rho_{\mathrm{o}}=1,44 \\
\mathrm{~T}_{\mathrm{cc}}=294 \mathrm{~K} \\
\left(-183^{\circ} \mathrm{C}\right)\end{array}$ & $\begin{array}{c}\text { Kerosene } \\
\mathrm{CH}_{1.96} \\
\rho_{\mathrm{c}}=0,83 \\
\mathrm{~T}_{\mathrm{cc}}=298 \mathrm{~K} \\
\left(25^{\circ} \mathrm{C}\right)\end{array}$ & 22 & 9200 & RD-170 & 2,6 \\
\hline $\begin{array}{c}\text { Oxygen } \\
\mathrm{O}_{2}\end{array}$ & $\begin{array}{c}\text { Hydrogen } \\
\mathrm{H}_{2} \\
\rho_{\mathrm{c}}=0,07 \\
\mathrm{~T}_{\mathrm{cc}}=20 \mathrm{~K} \\
\left(-253^{\circ} \mathrm{C}\right)\end{array}$ & 13,7 & 13400 & $\frac{\mathrm{RD}-57}{0120}$ & $\frac{6,2}{6}$ \\
\hline $\begin{array}{c}\text { Fluorine } \mathrm{F}_{2} \\
\rho_{\mathrm{o}}=1,5 \\
\mathrm{~T}_{\mathrm{cc}}=85 \mathrm{~K} \\
\left(-188^{\circ} \mathrm{C}\right)\end{array}$ & $\begin{array}{c}\text { Hydrogen } \\
\mathrm{H}_{2}\end{array}$ & 16 & - & RD-350 & 16,2 \\
\hline $\begin{array}{c}\text { Oxygen } \\
\mathrm{O}_{2}\end{array}$ & $\begin{array}{c}\text { Methane } \\
\mathrm{CH}_{4} \\
\rho_{\mathrm{c}}=0,43 \\
\mathrm{~T}_{\mathrm{cc}}=110 \mathrm{~K} \\
\left(-163^{\circ} \mathrm{C}\right)\end{array}$ & 22 & - & RD-190 & 3,4 \\
\hline
\end{tabular}

Table 1. Parameters of fuels and products of their combustion used in liquid rocket engines

As can be seen from the table, the following components of fuels are cryogenic (low-boiling): oxygen, hydrogen, fluorine and liquefied natural gases (LNG), of which methane is a representative.

Currently, the most common fuels are oxygen-kerosene (1st stage of the launch vehicle) and oxygen-hydrogen (2nd stage). These vapors from the point of view of use for liquid-propellant rocket engines in comparison with the $\mathrm{N}_{2} \mathrm{O}_{4}+\mathrm{UDMH}$ fuel pair, which has also received widespread use. It has both advantages and disadvantages.

Advantages:

1. High specific impulse Isp $\sim 450 \mathrm{~s}$.

2. Combustion products are environmentally friendly gases, consisting mainly of $\mathrm{H}_{2} \mathrm{O}$ vapors.

This is confirmed by the refusal to finance the project by V.N. Chelomei, in which it was supposed to use a high-power rocket engine, using $\mathrm{N}_{2} \mathrm{O}_{4}+\mathrm{UDMH}$ as 
fuel. An accident of such a launch vehicle would lead to an ecological disaster, making the territory of the cosmodrome a dead zone for decades.

For a similar reason, work on the use of fluorine for a liquid-propellant rocket engine was closed, although the fluorine-hydrogen pair exceeded the oxygenhydrogen pair in specific impulse.

3. Possibility of developing new LRE schemes: generatorless and threecomponent schemes.

Disadvantages

1. Low hydrogen density, which requires a large volume of tanks with liquid hydrogen and, as a consequence, an increase in the size of the launch vehicle.

The table of properties of fuels contains the conventional value «fuel density» $\rho_{f}$ :

$$
\rho_{f}=\frac{1+k_{m}}{\frac{1}{\rho_{c}}+\frac{k_{m}}{\rho_{0}}} \quad \begin{aligned}
& \rho_{c}-\text { density of the fuel; } \\
& \rho_{0}-\text { density of the oxidizer; } \\
& k_{m}-\text { mass ratio of the components. }
\end{aligned}
$$

The value of $\rho_{f}$ makes it possible to compare the mass characteristics for different LRE.

2. Increased requirements for the sealing of tanks, pipelines and other equipment of hydrogen systems, providing absolute isolation from air, with which hydrogen forms an explosive mixture, in contrast to oxygen, which ignites from the influx of heat or contact with organic substances.

3. The disadvantage of $\mathrm{H}_{2}$ and $\mathrm{O}_{2}$ is the low temperature required to ensure that both components stay in the liquid phase. Despite the various methods that provide thermal insulation of cryogenic systems, the issue of excluding the flow of heat to cryogenic systems cannot be solved without the use of special measures.

If in the process of storing low-boiling components in volumetric stationary tanks, standing on test benches, closed-loop systems can be used, where, with the help of a turbo-expander, the gas phase formed in the gas cushion is liquefied into the liquid phase, followed by the direction of the liquefied component back into the tank, then for the filled LV at the launch uses the operation of pre-launch cooling of LRE feed systems. This is necessary to ensure a cavitation-free operation of the turbo-pump unit (TPU) and the fuel supply system to the chamber. The supply elements (nozzles) are designed for a certain state of aggregation of the component supplied through them.

All this makes it practically impossible to use the cryogenic components $\mathrm{H}_{2}$ and $\mathrm{O}_{2}$ for LV that have been on alert for a long time. As a rule, at present the launch vehicle, fueled with cryogenic fuel, can be kept for no more than a few hours before launch (the launch vehicle R-9 is about nine hours).

4. Fuels that use $\mathrm{O}_{2}$ as an oxidizer are non-self-flammable components and various ignition devices are required to ignite them, which complicates the start-up process and reduces reliability.

As an example: in order to ensure reliability, a displacement feed system was chosen during the development of the «Apollo» propulsion system (refusal of TPU), and self-igniting components $\left(\mathrm{N}_{2} \mathrm{O}_{4}+\mathrm{UDMH}\right)$ were used as fuel. 


\section{On the history of the use of oxygen-hydrogen fuel in the USSR}

In the USSR, the use of hydrogen as a fuel component for liquid propellant rocket engines began in the early 60 -s at the initiative of S.P. Korolev with the beginning of work on the Lunar program, in which oxygen-hydrogen rocket engines were supposed to be used as a propulsion system for the upper stage on the flight trajectory to the Moon and in the L3 spacecraft when returning to Earth.

LRE 11D56 (with a thrust of 7,5 tons, OKB-2, chief designer A.M. Isaev) and 11D57 (with a thrust of 40 tons, OKB-165, chief designer A.M. Lyulka) were developed.

Although these engines passed fire tests, they were not in demand due to the closure of the Lunar program in 1976.

After S.P. Korolev (1907 - 1966) and the closure of the Lunar program of work on the development of rocket technology was headed by V.P. Glushko (19081989). Although V.P. Glushko was the creator of the liquid-propellant engine, but, having received under his leadership the enterprise S. Korolev, began the development of the «Energia» LV (1976-1987), for which an oxygen-hydrogen LRE RD-0120 (11D122) was developed at the KB Khimavtomatiki enterprise in Voronezh. The engine was created in the period from 1976 to 1984.

The issue of using methane as a hydrocarbon fuel arose as an alternative if it was necessary to replace kerosene in case of alleged difficulties with oil production, which were not confirmed.

From the point of view of using oxygen-methane fuel for liquid-propellant rocket engines, its main parameters (specific impulse, density) are similar to oxygen-kerosene pair with the only difference that methane, unlike kerosene, is a cryogenic component.

The RD-190 methane LRE developed at NPO «Energomash» («Ricksha» project) turned out to be unclaimed.

\section{Use of cryogenic components for life support systems (LSS) in manned space vehicles}

The LSS system is designed to create conditions that ensure the functioning of the crew on the spacecraft during a flight lasting from a week to a month. Such devices include the «Apollo» (USA), «Buran» (USSR), Space Shuttle (USA) spacecraft.

The main subsystems are the GSS gas supply system, the PSS power supply system, the thermal regime and the drinking water system.

The most acceptable for the human body is the nitrogen-oxygen atmosphere, which is similar in property to the earth's. This is ensured by the supply of liquid oxygen at the SS.

The power supply system is designed to generate electricity necessary for the onboard systems to function in flight. This system belongs to the class of power plants with a generator for direct conversion of chemical energy into electrical energy. In the electrochemical electric generator ECHG, the reaction of hydrogen oxidation occurs with the formation of water and the release of heat. Thus, in addition to electricity, the SS is provided with drinking water and 
maintaining a thermal regime. Oxygen and hydrogen are stored on board the spacecraft in a liquid state.

\section{CONCLUSION}

1. In the 21-st and, apparently, in the 22-nd century, as engines for rockets used in space flights, it will be optimal to use LRE as power plants, which are converters of chemical energy into thermal energy and create thrust due to kinetic energy emanating from nozzles of gases formed as a result of the oxidation of hydrocarbon or hydrogen by oxygen, which are part of the fuel [1-5].

2. The most optimal option is to use cryogenic components: oxygen and hydrogen as a fuel for LRE.

3. The emergence of other schemes of power plants capable of providing thrust for flights into deep space is unlikely in the near future.

\section{REFERENCES}

1. A.M. Arkharov, Achievements and problems of engineering cryology, J. Chemical and Petroleum Engineering 43, 7-8 (2007)

2. A.M. Arkharov, Cryology-potential and problems, J. Chemical and Petroleum Engineering 38, 7-8 (2002)

3. D.A. Yagodnikov, A.V. Voronetskii, N.M. Pushkin, J. Combustion, Explosion, and Shock Waves 31, 4 (1995)

4. A.A. Dorofeev, D.A. Yagodnikov, High Temperature 56, 2 (2018)

5. F.V. Pelevin, N.I. Avraamov, N.Y. Iryanov, S.A. Orlin, V.V. Lozovetskii, A.V. Ponomarev, J. of Eng. Phys. and Thermophysics 91, 3 (2018)

6. V.N. Zernov, E.P. Seregin, Liquid propellants (1975)

7. G.G. Gakun, Construction and design of rocket engine (1989)

8. Yu.P. Semenov, Space complex «Buran» (1995)

9. N.I. Shumeiko, Manned flights to the Moon. The results of the science of technology. Database VINITI, «Mechanical Engineering», «Rocket Engineering»

10. Directory «Engines for aircraft, rocket, marine, industrial», Materials of Conference «AKS» (2000)

11. V.P. Glushko, «Cosmonautics», Soviet Encyclopedia (1985) 